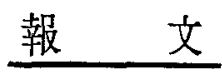

電熱化学特集

\title{
窒素プラズマジェットによる窒化モリブデンの製造*
}

\section{Formation of Molybdenum Nitride by Means of Nitrogen Plasma Jet}

\author{
松本修** \\ Osamu Matsumoto
}

\section{1 緒言}

高温における化学反応は種々の方法で試みられてきた が得られる温度に限度があり，行ないらる反忘にも制限 があった.プラズマジェットが開発されて以来，数千度 という温度が比較的容易に得られるようになり，かなり 広い分野で利用されるよらになった

窒素プラズマジェットと金属との反応による窒化物の 生成は非移送方式プラズマトーチを用いて行なわれ， $\mathrm{TiN}^{3), 4)}, \mathrm{Mg}_{3} \mathrm{~N}_{2}{ }^{3)}, \mathrm{ZrN}^{51}, \mathrm{BN}^{(5)}$ などが生成されてい る.

著者ら”はこれまで用いられてきた非移送方式プラズ マトーチにかわって移送方式プラズマトーチを用いるこ とにより試料の温度を高め，反応時間を長くできる点に 着目して窒素プラズマと金属との反応によって窒化物を 生成することを試み，さきに窒化タンタルを生成した。

今回恃同様の装置を用いて金属モリブデンと窒素プラ ズマの反応によって窒化モリブデンの生成を試みた。 Stokes ら ${ }^{3)}$ は非移送方式プラズマト一チを用いては窒 化モリブデンの生成は著しく因難であると述べている が，著者らは $\mathrm{Mo}_{2} \mathrm{~N}$ 含有率約 $40 \%$ の生成物をらるこ とができた。

\section{2 実験}

\section{1 試料}

モリブデン金属：日本タングステン（株）製モリブデ ン棒（径 $10 \mathrm{~mm}$, 純度 $99.96 \%$ ) を $10 \mathrm{~mm}$ の長さに切 断して一回の試料とした．金属中のおもな不純物は $\mathrm{Fe}$ $0.020 \%, \mathrm{Ni} 0.017 \%$ である.

アルゴンおよび窒素 : 市販ボンベぶめ高純度品をその まま使用した。

\section{2 装置}

前報》と同様の装置を用いた。

* 高温にお什る化学反応の研究（第 2 報） Studies of Chemical Reactions at High Temperature (Part 2) 電気化学協会第 33 回大会（昭和 41 年 4 月早积田大学）にて薄演

** 青山学院大学理工学部化学教室（東京都世田分谷区迴沢町 576 番地)

\section{3 実験方法}

窒化物の生成反応は前報” と同様の方法によって行な ot.

金属表面の温度測定は WERK 社製 Micropyrometer を使用し, 反店容器側面の監視空を用いて行なった。

生成物中の空素の分析は次の方法 ${ }^{8)}$ によって行なっ た. 試料 (生成物) 約 $50 \mathrm{mg}$ を精ひょうし，パイレッ クス試験管に入れ，水酸化ナトリウム約 $5 \mathrm{~g}$ を加える. アルゴン気流中で加熱して発生するアンモニアを $2 \%$ 小 ウ酸約 $200 \mathrm{ml}$ を入れたコニカルビーカ一中に導く. 反 応終了後ブロムクレゾールグリーン+メチルレッド (5 ：1）混合指示䓠を用いて $1 / 100$ 規定塩酸で滴定して 塩酸の使用量から試料中の窒素含有率を求めた.

\section{3 実験結果および考察}

\section{1 生成物の確認}

金属モリブデンに窒素プラズマを衝撃すると黒色粉末
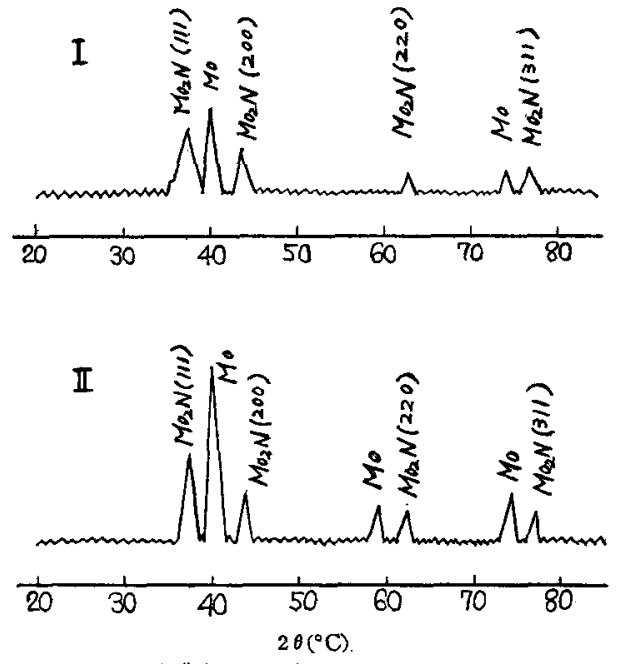

操作条件 $100 \mathrm{~A}, 3 l / \mathrm{min}, 5 \mathrm{~min}$ $I ：$ 水椧じゃ管付着物，II：ルツボその他付着物 图 1 反応生成物のX線回折図（径 $7 \mathrm{~mm}$ ノズル使用） 

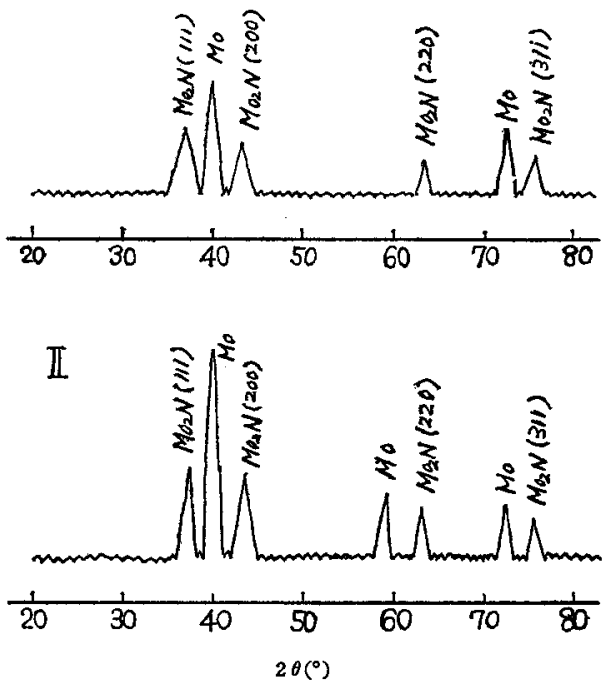

操作条件 : $100 \mathrm{~A}, 3 \mathrm{l} / \mathrm{min}, 5 \mathrm{~min}$

$I ：$ 水冾じゃ管付着物，II：ルッボその他付着物

図 2 反応生成物のX線回折図（住 $5 \mathrm{~mm}$ ノズル使用)

が水冷じゃ管，水冷銅ルツボおよび器壁などに付着して 捕集される。得られた生成物の確認はX線回折および化 学分析によった.

$\mathrm{X}$ 線回折図の一例を図 1 および図 2 に示す．図 1 は $7 \mathrm{~mm} \phi$ のノズルを用いた場合に得られた生 成物のX線回折図である.水冷じ管付着物およ びルツボその他の付着物のいずれにも $\mathrm{Mo}_{2} \mathrm{~N} の$ 存在が確認される（生成物の格子定数を求めると $a=4.16 \AA$ で $\mathrm{Mo}_{2} \mathrm{~N}$ の格子定数と一致する).し かしながら末反応の金属モリブデンがかなり含ま れていることが認められる. 水冷じゃ管付着物は ルツボその他の付着物に比べて結晶があまり成長 していない.

図 2 は $5 \mathrm{~mm} \phi$ のズルを用いた場合に得られ

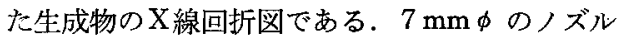
を用いた場合と同様に $\mathrm{Mo}_{2} \mathrm{~N}$ の生成が 確認され る. また水冷じゃ管付着物はその他のものに比べ て結晶があまり成長していない。

ノズル径の相違による生成物の相違をみると， 水冷じゃ管付着物においては $7 \mathrm{~mm} \phi$ のズルを

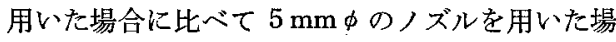
合に幾分結晶成長が見られる，またルツボその他 の付着物をみると， $5 \mathrm{~mm} \phi$ のズルを用いた場 合の生成物が $7 \mathrm{~mm}$ のノズルを用いた場合のそ れに比べて結晶成長が諗められ，とくに 200 面 の成長加著しい.

図 1 および図 2 のX線回折に用いた試料の空素 含有淙を化学分析により求め, 得られた結果を表 1 に示す. $7 \mathrm{~mm} \phi, 5 \mathrm{~mm} \phi$ いずれのノズルを用
表 1 生成物の窒素分析結果

\begin{tabular}{|c|c|c|c|c|c|c|}
\hline & \multicolumn{3}{|c|}{ 径 $5 \mathrm{~mm}$ ノズル } & \multicolumn{3}{|c|}{ 径 $7 \mathrm{~mm} ノ ス ゙$} \\
\hline & $\begin{array}{l}\text { 品 } 几 \\
\text { 付 着 }\end{array}$ & その他 & 計 & 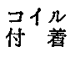 & その他 & 計 \\
\hline $\mathrm{Mo}+\mathrm{Mo}_{2} \mathrm{~N} \mathrm{mg}$ & 42.8 & 59.2 & 102 & 60.1 & 53.1 & 113 \\
\hline $\mathrm{mg}$ & 1.16 & 1.10 & 2.26 & 2.14 & 0.91 & 3.05 \\
\hline $\mathbf{N}$ & 2.64 & 1.86 & 2.21 & 3.50 & 1.71 & 2.70 \\
\hline $\mathrm{Mo}_{2} \mathrm{~N}$ & 16.6 & 16.4 & 33.0 & 31.5 & 13.4 & 44.7 \\
\hline $\mathrm{Mo}_{2} \mathrm{~N}$ & 38.9 & 27.4 & 32.4 & 52.4 & 25.2 & 39.7 \\
\hline
\end{tabular}

反店条件 電流 $100 \mathrm{~A}, \mathrm{~N}_{2}$ 流量 $3 \mathrm{l} / \mathrm{min}$ 反店時間 5 分

いた場合にも水冷じゃ管付着物がルツボその他の付着物 に比べて窒素含有率が高い。また $7 \mathrm{~mm}$ および $5 \mathrm{~mm}$ фのノズルによる生成物の相違をみると $7 \mathrm{~mm} \phi$ の ズルを用いた場合の生成物は $5 \mathrm{~mm}$ の場合のそれより も水冷じゃ管付着物の窒素含有率が高いが，ルツボその 他の付着物窒素含有率は $5 \mathrm{~mm} \phi$ のノズル用いた場合 加高い。

\section{2 生成反応に用いたエネルギー}

a）陽極に金属モリブデンを用いた場合のトーチの特 性：移送方式プラズマト一チの陽極水冷銅ルツボ上に金 属モリブデンを瑱いた場合の窒素プラズマジェットの特 性を求め, 得られた結果を図 3〜5 に示す.

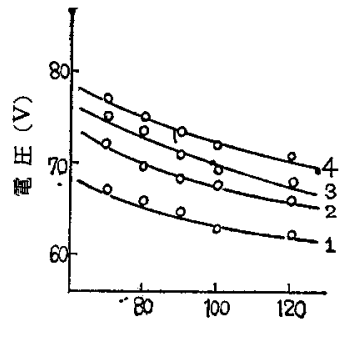

龟流 (A)

$1.5 \mathrm{l} / \mathrm{min}, 2: 2 \mathrm{l} / \mathrm{min}, 3: 3 \mathrm{l} / \mathrm{min}, 4: 4 l / \mathrm{min}$ I : ノスル徍 $7 \mathrm{~mm}$, II : ノスル徍 $5 \mathrm{~mm}$

図 3 種↔の $\mathrm{N}_{2}$ 流量における電流-電位曲線
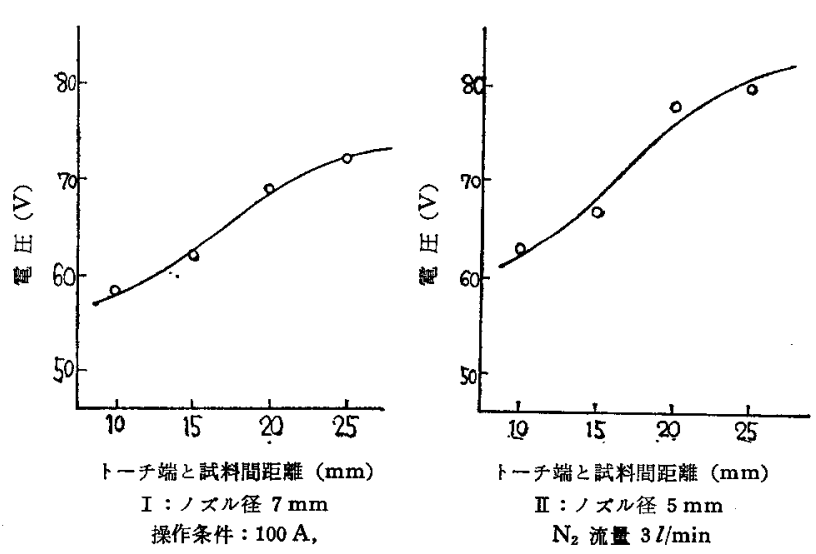

図 4 電圧に及ぼすトーチ端と試料間距離の影饗

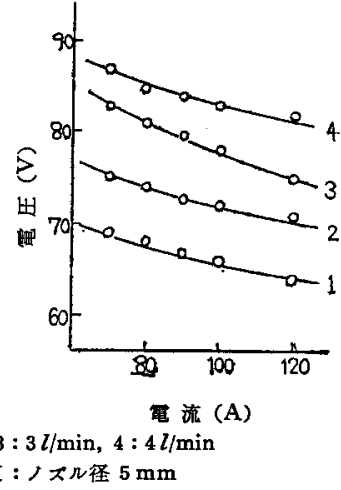




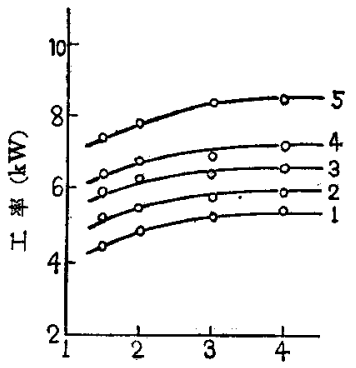

$\mathrm{N}_{2}$ 流 $(l / \mathrm{min})$

I : ノズル径 $7 \mathrm{~mm}$

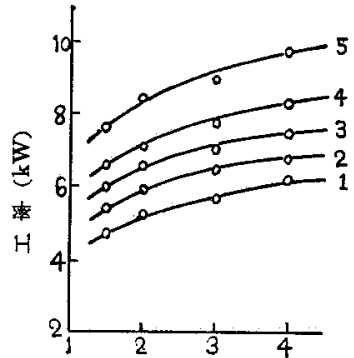

$\mathrm{N}_{2}$ 流量 $(l / \mathrm{min})$ II : $ノ ル$ 径 $5 \mathrm{~mm}$
$1: 70 \mathrm{~A}, 2: 80 \mathrm{~A}, 3: 90 \mathrm{~A}, 4: 100 \mathrm{~A}, 5: 120 \mathrm{~A}$

図 $5 \mathrm{~N}_{2}$ 流量と工皮の関係

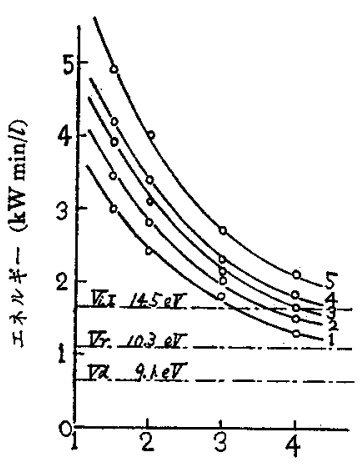

$\mathrm{N}_{2}$ 流量 $(l / \mathrm{min})$

I : ノスル徍 $7 \mathrm{~mm}$

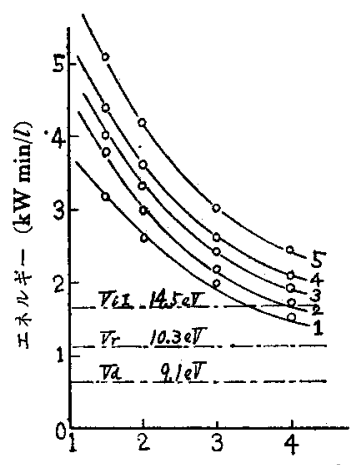

$\mathrm{N}_{2}$ 流量 $(\mathrm{l} / \mathrm{min})$ II : ズル径 $5 \mathrm{~mm}$ $1: 70 \mathrm{~A}, 2: 80 \mathrm{~A}, 3: 90 \mathrm{~A}, 4: 100 \mathrm{~A}, 5: 120 \mathrm{~A}$

区 $6 \mathrm{~N}_{2}$ 流量とエネルギ一の関係

図 3 には種々の窒素流量における電流と電圧の関係を 示才. 窒素の同一流量においては電流の増加にしたがっ て電圧の減少がみられる。また $5 \mathrm{~mm}$ のノズルを用い た場合に $7 \mathrm{~mm} \phi$ ノズルを用いた場合に比べて電圧が 高いことが認められた。

図 4 にはトーチ試料間の距離と電圧の関係を示す. 距 離が $20 \mathrm{~mm}$ 以上においては電圧はあまり増加しない。 したがって以後の実験はトーチと試料閒の距離を $20 \mathrm{~mm}$ として行なった。

図 5 には図 3 の結果に基づいて窒素流量と工率

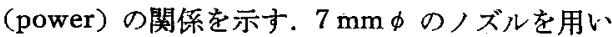
た場合には流量の増加にともなって工率はほぼ一

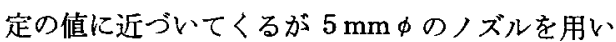
た場合には電流の増加にともなって窒素流量の増 加とともに工率が増加する，

b）生成反态に用いたエネルギー：図 5 の結果 にもとずいて種々の電流における窒素流量よ単位 流量当たりのエネルギー $(\mathrm{kW} \mathrm{min} / l)$ の関俰を 求め, 得られた結果を図 6 に示す。率素流量の増 加にともなって単位流量当たりのエネルギーの減 少がみられるが $3 l / \mathrm{min}$ を越えるとほぼ一定の値
となる。

図 6 には穻素分子の解離エネルギー $\left(V_{d}\right)$ および窒 素原子のイオン化ポテンシャル $\left(V_{i I}\right)$ をあわせて示し たが窒秦分子の解離には十分なエネルギーが与えられて 、ると考えられる. 一方窒素原子のイオン化には十分な エホルギーがรえられているとはいい切れない．しかし ながら窒素の共鳴励起電圧 $\left(V_{r}\right)$ を考虑すると窒秦の イオン化もある程度進んでいると考えられる。したがっ て，窒素プラズマジェット中には窒素原子が多く存在 し，れの他窒素イオンおよび電子がかなり存在し, さら に少量の窒素分子が存在していると考えられる.

図 6 において窒素プラズマジェットに与えられたエネ ルギーが求められたがこれがすべてモりブデンの窒化反 応に用いられたわけではない.トーチの内部，反応容 器, 銅ルツボなどは水冾を必要とする。したがって窒素 プラズマジェットに与えられたエネルギーの一部はこれ らの冷却水によって持ち去られる。したがって窒化物の 生成反忘に用いられるエネルギーはこれらを差し引いた ものを考える必要がある。冷却水の流量および入口，出 口の温度差より求めた泠却水のエネルギー増加を差し引 いて得られた窒素プラズマジェットのエネルギーと窒素

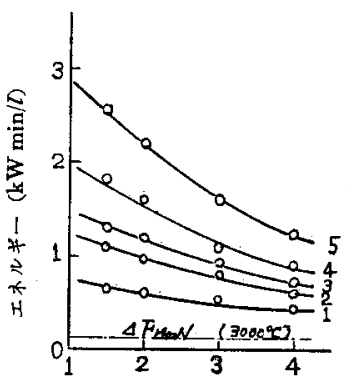

$\mathrm{N}_{2}$ 流量 $(l / \mathrm{min})$ I : ノスル径 $7 \mathrm{~mm}$

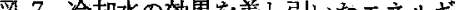
と $\mathrm{N}_{2}$ 流量の関係

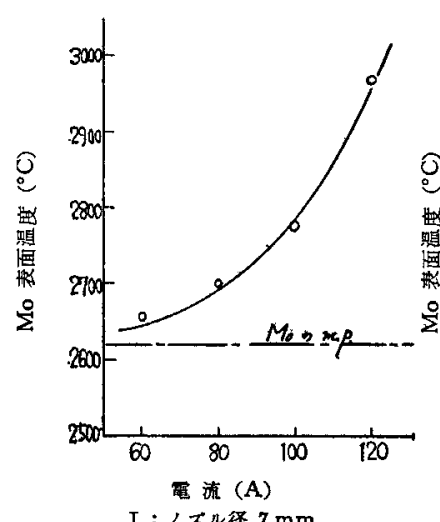

I : ノスル徍 $7 \mathrm{~mm}$

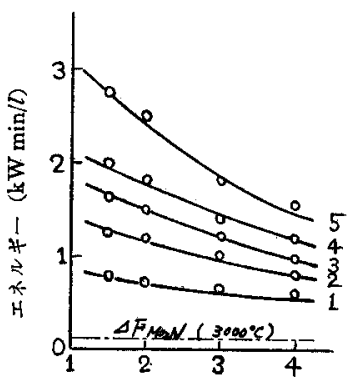

$\mathrm{N}_{2}$ 流量 $(l / \mathrm{min})$ II : ズル各 $5 \mathrm{~mm}$
$\mathrm{N}_{2}$ 流量 $: 3 \mathrm{l} / \mathrm{min}$

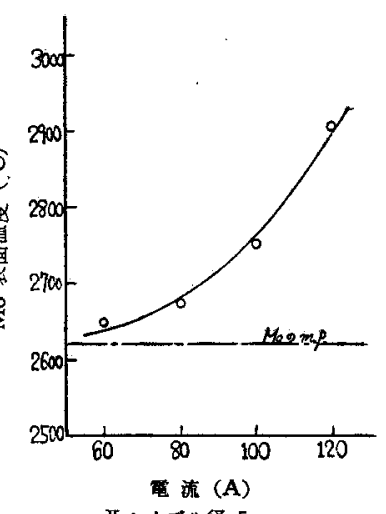

II : ノスル径 $5 \mathrm{~mm}$
図 8 Mo 表面榅度之䉓流の関俰 
流量の関保を図 7 に示す.

$\mathrm{Mo}_{2} \mathrm{~N}$ の生成自由エネルギーは Stokes ら ${ }^{33}$ によって 求められた。 $3000^{\circ} \mathrm{C}$ に扔引る $\mathrm{Mo}_{2} \mathrm{~N}$ の生成自由エネ ルギーを図 7 にあわせて示した. $\mathrm{Mo}_{2} \mathrm{~N}$ の生成には十 分なエネルギーが与えられていると考えられる。

\section{3 反応温度の測定}

空素プラズマジェットが衝突しているモりブデン金属 の表面温度を Micropyrometer 用いて測定した，用い たフィルターは $\lambda=0.65$ である。得られた結果を図 8 飞示寸.測定值は金属の放射摔を考慮して Wien の式 ${ }^{19}$ を用いて補正した。

$$
1 / T-1 / T_{B}=\lambda \ln E_{\lambda} / C
$$

ここで $T$ は真の温度, $T_{B}$ は測定温度, 2 は波長, $C$ は定数， $E_{\lambda}$ 注波長入に招ける放射率である.

電流 $60 \mathrm{~A}$ 亿おいて金属モリブデン表面はすで们融点 以上に達して溶融状態にある.

3.4 反応に及ぼす雷流, ガス流量およひ時間の影整

a）電流の影響 : 種々の電流によって得られた反応生 成物の収量, 窒素含有率技よびそれより得られた $\mathrm{Mo}_{2} \mathrm{~N}$ 含有率を表 2 に示す. 表 2 より得られた一定反忍時間 (5分)における $\mathrm{Mo}_{2} \mathrm{~N}$ の生成量, 窒素固定量および導 入窒素を理想気体と考えた場合の窒素固定効率を図 9 に 示寸.

表 2-1 生成反応に及ぼす電流の影響 (径 $7 \mathrm{~mm}$ ノズル)

\begin{tabular}{|c|c|c|c|c|c|c|}
\hline & & $70 \mathrm{~A}$ & $90 \mathrm{~A}$ & $100 \mathrm{~A}$ & $120 \mathrm{~A}$ & 反危条件 \\
\hline \multicolumn{2}{|c|}{$\mathrm{Mo}+\mathrm{Mo}_{2} \mathrm{~N} \mathrm{mg}$} & 38.0 & 83.4 & 113 & 125 & 径 $7 \mathrm{~mm}$ ノスル \\
\hline $\mathrm{N}$ & $\%$ & 2.50 & 2.70 & 2.65 & 2.62 & $\mathrm{~N}_{2}$ 流量 $3 l / \mathrm{min}$ \\
\hline $\mathrm{Mo}_{2} \mathrm{~N}$ & $\%$ & 37.2 & 40.2 & 39.6 & 38.6 & 区応時間 5 分 \\
\hline Mo & $\%$ & 62.8 & 59.8 & 60.4 & 61.4 & \\
\hline
\end{tabular}

表 2-2 生成反心に及ぼす電流の影響 (徍 $5 \mathrm{~mm}$ ノズル)

\begin{tabular}{|c|c|c|c|c|c|c|}
\hline & $70 \mathrm{~A}$ & $90 \mathrm{~A}$ & $100 \mathrm{~A}$ & $120 \mathrm{~A}$ & 反店策件 \\
\hline \multicolumn{2}{|c|}{$\mathrm{Mo}+\mathrm{Mo}_{2} \mathrm{~N} \mathrm{mg}$} & 40.7 & 89.9 & 102 & 125 & 径 $5 \mathrm{~mm} / ス ゙ ル$ \\
\hline $\mathrm{N}$ & $\%$ & 1.90 & 2.28 & 2.21 & 2.23 & $\mathrm{~N}_{2}$ 流量 $3 \mathrm{l} / \mathrm{min}$ \\
\hline $\mathrm{Mo}_{2} \mathrm{~N}$ & $\%$ & 27.9 & 33.5 & 32.5 & 32.8 & 反怘時間 5 分 \\
\hline Mo & $\%$ & 72.1 & 66.5 & 67.5 & 67.2 & \\
\hline
\end{tabular}

$7 \mathrm{~mm} \phi$ のノズルを用いた場合が $5 \mathrm{~mm} \phi$ のノズルを 用いた場合に比べて空素固定量が多い、いずれの場合に も電流増加にともなって窒素固定量が増加するが $100 \mathrm{~A}$ を越えるとあまり增加がみられなくなる，使用窒素量に 対する窒素固定の效率は $0.01 \sim 0.02 \%$ という低い值で ある。

b）空素流量の影響：窒素流量を変化させて行なった 反応で得られた生成物の収量および窒素含有率, $\mathrm{Mo}_{2} \mathrm{~N}$ 含有率を表 3 に示す。表 3 より得られた一定反応時間 (5 分) における $\mathrm{Mo}_{2} \mathrm{~N}$ の生成量, 窒素固定量および導 入窒素を理想気体と考えた場合の窒素固定効率を図 10

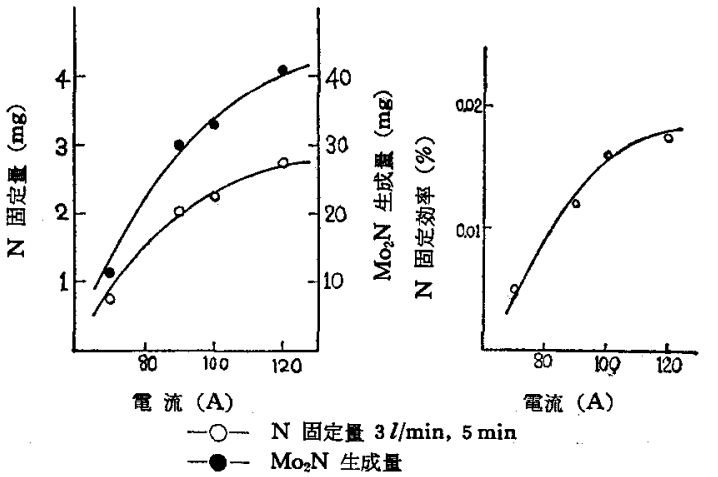

図 9-1 電流と生成量の関係（径 $7 \mathrm{~mm}$ ノズル)
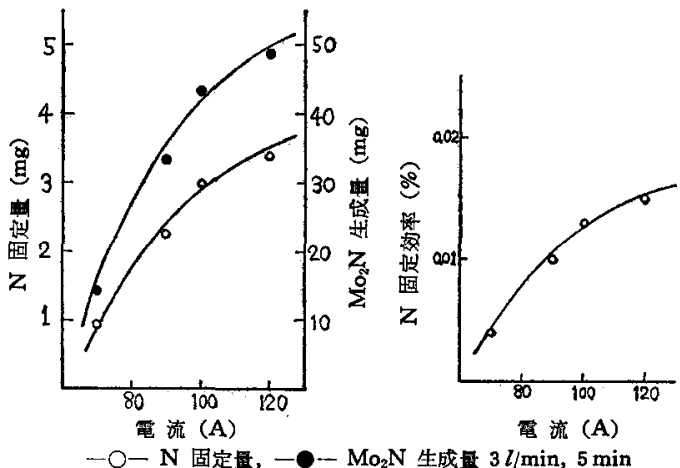

一O- $\mathrm{N}$ 固定量

罒 9-2 電流と生成量の関係 (径 $5 \mathrm{~mm}$ ノズル)

表 3 生成反応に及活す窒素流量の影響

\begin{tabular}{|c|c|c|c|c|c|c|}
\hline & & $\stackrel{1.5}{l / \mathrm{min}}$ & $2 l / \mathrm{min}$ & $3 l / \mathrm{min}$ & $4 \mathrm{l} / \mathrm{min}$ & 反忘策件 \\
\hline \multicolumn{2}{|c|}{$\mathrm{Mo}+\mathrm{Mo}_{2} \mathrm{~N} \mathbf{m g}$} & 50.0 & 75.0 & 113 & 124 & 径 $7 \mathrm{~mm} ノ x ル$ \\
\hline $\mathbf{N}$ & $\%$ & 2.74 & 2.70 & 2.65 & 2.62 & 電流 $100 \mathrm{~A}$ \\
\hline $\mathrm{Mo}_{2} \mathrm{~N}$ & $\%$ & 40.8 & 40.2 & 39.6 & 38.6 & 反心時間 5 分 \\
\hline No & $\%$ & 59.2 & 59.8 & 60.4 & 61.4 & \\
\hline
\end{tabular}

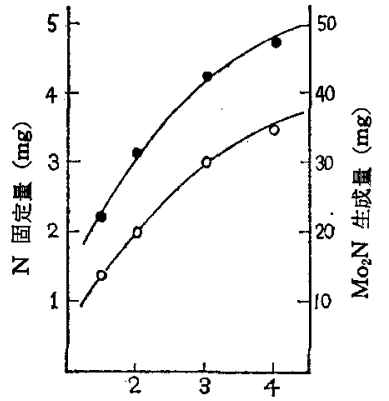

$\mathrm{N}_{2}$ 流显 $(l / \mathrm{min})$

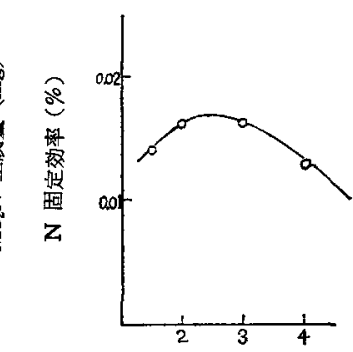

$\mathrm{N}_{2}$ 流量 $(l / \mathrm{min})$
一O- $\mathrm{N}$ 固定量, $-0-\mathrm{Mo}_{2} \mathrm{~N}$ 生成量 ノズ径 $7 \mathrm{~mm}, 100 \mathrm{~A}, 5 \mathrm{~min}$

因 $10 \quad \mathrm{~N}_{2}$ 流量と生成量の関倸

に示す.

窒素流量が $3 l / \mathrm{min}$ までは流量増加にともない生成 


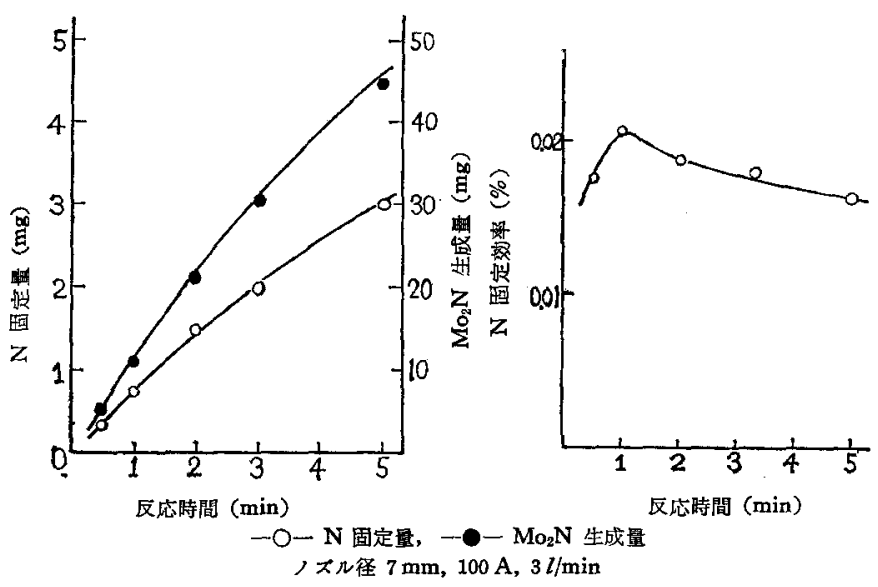

図 11 反応時間と生成量の関绿

表 4 生成反応に及ぼす反応時間の影響

\begin{tabular}{|c|c|c|c|c|c|c|c|}
\hline & & $\begin{array}{c}0.5 \\
\min \end{array}$ & $1 \mathrm{~min}$ & $2 \min$ & $3 \mathrm{~min}$ & $5 \mathrm{~min}$ & 反忘篓件 \\
\hline \multicolumn{2}{|c|}{$\mathrm{Mo}+\mathrm{Mo}_{2} \mathrm{~N} \mathrm{mg}$} & 11.5 & 28.5 & 51.0 & 73.0 & 113 & \multirow{4}{*}{ 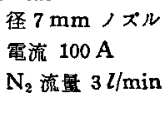 } \\
\hline $\mathbf{N}$ & $\%$ & 2.85 & 2.80 & 2.75 & 2.82 & 2.65 & \\
\hline $\mathrm{Mo}_{2} \mathrm{~N}$ & $\%$ & 41.9 & 41.2 & 40.5 & 41.4 & 39.6 & \\
\hline Mo & $\%$ & 58.1 & 58.8 & 59.5 & 58.7 & 60.4 & \\
\hline
\end{tabular}

量の直線的増加がみられるが $3 l / \mathrm{min}$ を越えるとほぼ一 定の值となる，窒素固定の効率をみると流量 $2.5 \mathrm{l} / \mathrm{min}$ 付近に極大点をむつ曲線が得られる. 反応に奇与する空 素量弾位金属モリブデン量に対してあまり変わらない ことを示している.

c) 反応時間の影響：電流 $100 \mathrm{~A}$, 窒素流量 $3 l / \mathrm{min}$ の条件で反応を行なった場合の反応時閒と生成物の収量 括よび窒素含有率， $\mathrm{Mo}_{2} \mathrm{~N}$ 含有率を表 4 に示す。表 4 より得られた反応時閒に対する $\mathrm{Mo}_{2} \mathrm{~N}$ の生成量, 啙秦 固定量および空素の固定効率を図 11 に示す. 反応蛙間 が短い間は生成量はほぼ直線的に增加するが次第に曲線 のこら配が減少してくる。これを窒秦の固定效率からみ ると反応時間 1 分程度に極大点がみられる，反応時間が 短い閒は金属表面がほぼ金属モリブデンであり，等素プ ラズマとの反応が進行すると思われるが反応が進行する につれて表面に $\mathrm{Mo}_{2} \mathrm{~N}$ が生成して反応が抑制されると 考えられる。

\section{5 罣化モリブデンの生成反応の考察}

3.1〜3.4に述べたごとく移送方式プラズマト一チを 用いて金属モリブデンに窒素プラズマジェットを衝撃し た場合に $\mathrm{Mo}_{2} \mathrm{O}$ の生成が確認された.

3.2 に述べたごとく反応にあずかるプラズマの種とし ては窒素原子, 窒素イオン, 電子および少量の窒素分子 を考えることができる．一方金属モリブデンは陽極を形 成しているため他の部分に比べて電圧が高い，したがっ てこれに電子が衝突してモリブデン原子がたたき出され る. またプラズマジェットの有するエネルギーによる加
熱によって金属表面は溶融状態となってい る.それゆえ，金属表面よりの蒸発も考虑 に入れる必要があろう。したがってモリブ デンの種としてはガス状モリブデンおよび 液体を考えることがでさる。

以上のことから金属モリブデンと空素プ ラズマジェットの反忘としては，

$$
\begin{aligned}
& \mathrm{Mo}^{+}+e \rightarrow \mathrm{Mo} \\
& 2 \mathrm{Mo}+1 / 2 \mathrm{~N}_{2} \rightarrow \mathrm{Mo}_{2} \mathrm{~N} \\
& 2 \mathrm{Mo}+\mathrm{N} \rightarrow \mathrm{Mo}_{2} \mathrm{~N} \\
& 2 \mathrm{Mo}(l)+\mathrm{N} \rightarrow \mathrm{Mo}_{2} \mathrm{~N} \\
& 2 \mathrm{Mo}+\mathrm{N}^{+} \rightarrow \mathrm{Mo}_{2} \mathrm{~N}^{+} \\
& \mathrm{Mo}_{2} \mathrm{~N}^{+}+e \rightarrow \mathrm{Mo}_{2} \mathrm{~N}
\end{aligned}
$$

などが侾えられる.

反応生成物をみると水冷己ゃ管付着物は ルツボその他付着物に比べて窒素含有率が高いがその結 晶成長注あまりみられない，水冷じゃ管付着物の生成反 态はガス状モリブデンと窒素原子との反応が主反心であ り，両者の衝突確率が低く，生成した $\mathrm{Mo}_{2} \mathrm{~N}$ はその結 晶成長が困難であると考えられる。一方ルツボその他付 着物は上記の原子間反応よりもむしろ液体金属の格子間 に窒素原子が入り込み， $\mathrm{Mo}_{2} \mathrm{~N}$ の格子を形成し，徐冷 されて結晶が成長すると考えられる，モリブデンの結晶 構造は $a=3.14 \AA \AA$ の体心立方格子である.モリブデン に窒素が侵入して hole を $1 / 2$ の割合で充てんして $\mathrm{NaCl}$ 型の $\mathrm{Mo}_{2} \mathrm{~N}$ の結晶格子を形成する.X 線回折の 結果, 結晶成長の著しい水冷じゃ管以外の付着物に拉 いては 111 面执よび 200 面の成長がとくに著しい. $\mathrm{Mo}_{2} \mathrm{~N}$ 結晶の形成は空素の容積が小で高エネルギーを゙ 有することおよびモリブデン原子間の距離が短いことが 望ましい，したがって液体モリブデンと窒素原子の反応 によって $\mathrm{Mo}_{2} \mathrm{~N}$ の結晶は比較的容易に形成されると思 われる.ことに $5 \mathrm{~mm}$ のノズルを用いた場合に $7 \mathrm{~mm}$

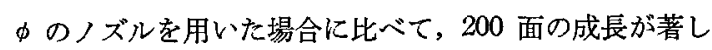
いことがこれを裏づける。

以上のように移送方式プラズマトーチを用いた場合の 金属モリブデンと蠓素プラズマの反応は

$$
\begin{aligned}
& \mathrm{Mo}^{+}+e \rightarrow \mathrm{Mo} \\
& 2 \mathrm{Mo}+\mathrm{N} \rightarrow \mathrm{Mo}_{2} \mathrm{~N}
\end{aligned}
$$

および

$$
2 \mathrm{Mo}(l)+\mathrm{N} \rightarrow \mathrm{Mo}_{2} \mathrm{~N}
$$

が主度応であり，これが同時に起こっていると考えられ 歹.

終りに本研究をご指導下さいました青山学院大学理工学部長 早川保昌教授に厚くお柇申し上げます。

(昭 $41-5-12$ 受理)

\section{文献}

1) A.S. Kana'áu,J.L. Margrave, "Advances in Inorganic Chemistry and Radiochemistry" Vol. 6, p. 143 (1964), Aca- 
demic Press.

2) 松本修, 早川保昌, 本読 33, 677 (1965).

3) C.S. Stokes, W.W. Knipe, Ind. Eng. Chem. 52, 287 (1960).

4) W. Oppenmann, Monatsber. Deut. Akad. Wiss. Berlin G, $92(1964)$.

5) F.L. Ringuett, A.M. Lojus, R. Collonguess, Compt. Reud.
258, 221 (1964)

6) F.M. Bosch, Silicate Ind. 27, 587 (1962).

7) 松本 修, 早川保昌，本誌 34，775 (1966)。

8) R.G. Passer, A. Haut, R.J. Julietti, Analyst. 87, 417 (1962).

9) W.D. Kingery, "Property Measurements at High Tempe rature" p. 12. (1959), Jon Wiley and Sons.

\title{
電熱化学特集
}

\section{高炭素フェロクロムの酸化* \\ Oxidation of High Carbon Ferrochrome}

\author{
石井 正 司**, 吉田哲 郎***, 武 井 武*** \\ Masaji IHsII, Tetsuro YoshIDA, Takeshi TAKEI
}

\section{1 緒}

름

低炭素フェロクロムは金属材料の合金成分として非常 に重要な位置を占めているので，これを効率良く製造す ることは工業的にきわめて重要である．低炭素フェロク ロムは通常高炭素フェロクロムを電気炉で溶融し, 酸化 することによって製造されている，この方法咳価に当 たるので近年高炭素フェロクロムを固相のままで脱炭す る方法が開発され，実用に供されているが(1) 尚，この方 法の反応機構はいまだ十分明らかではないか.

高炭素フェロクロム中の炭素はクロムおうよび鉄とカー バイドを作っている. 固相脱炭反応の際にはこのカー バイド中の炭素は外部から供給される酸素と化合して, 主として一酸化炭素となり系外に除去されると考えられ る.この脱炭反応の際酸素の供給がカーバイドを取り巻 く気相からなされるか，あるい酸化物としての固相か らなされるかによって脱炭の様子は異なっている.

著者らは高炭素フェロクロムと気相中の酸素との反応 を明らかにする目的で実験を行なったのでその結果をこ こ比報告する。

\section{2 熱力学的考察}

クロム-鉄-炭素系においては通常の高炭素フェロクロ 厶は $(\mathrm{Cr}, \mathrm{Fe}){ }_{7} \mathrm{C}_{3},(\mathrm{Cr}, \mathrm{Fe})_{23} \mathrm{C}_{6}$ などの複合カーバイド およびこれらのカーバイドと $\alpha$-鉄・クロム相の共晶組 織より成っている(5),6).ここでは主として $(\mathrm{Cr}, \mathrm{Fe})_{7} \mathrm{C}_{3}$ を中心として，このカーバイドがどのような反応を行な らかを考えることにする．単純化として考えるためにま

* 高炭菜フェロクロムの粉末治金的眖炭反芯の研究（第 1 報） Studies on the Powder Metallurgical Decarburization of High Carbon Ferrochrome (Part 1). 第 11 回化学系学㙝会

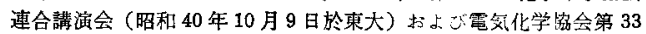
回大会（昭和 41 年 4 月 6 日於早大）にて一部講演

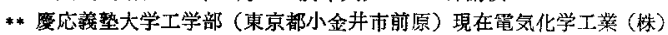
中央研究所 (東京都町田市本町田 611)

*** 鹿灾義獒大学工学部（東京都小金井市前原）
ず鉄を除外して反応を推定する，

$\mathrm{Cr}_{7} \mathrm{C}_{3}, \mathrm{Cr}_{23} \mathrm{C}_{6}$ と酸素および酸化物との反応を考える とつぎのようになる.

(1) カーバイドと気相酸素との反応

(1) $4 \mathrm{Cr}_{7} \mathrm{C}_{3}+27 \mathrm{O}_{2}=14 \mathrm{Cr}_{2} \mathrm{O}_{3}+12 \mathrm{CO}$

(2) $4 \mathrm{Cr}_{23} \mathrm{C}_{6}+81 \mathrm{O}_{2}=46 \mathrm{Cr}_{2} \mathrm{O}_{3}+24 \mathrm{CO}$

(3) $46 \mathrm{Cr}_{7} \mathrm{C}_{3}+27 \mathrm{O}_{2}=14 \mathrm{Cr}_{23} \mathrm{C}_{6}+54 \mathrm{CO}$

(4) $2 \mathrm{Cr}_{7} \mathrm{C}_{3}+3 \mathrm{O}_{2}=14 \mathrm{Cr}+6 \mathrm{CO}$

(5) $\mathrm{Cr}_{23} \mathrm{C}_{6}+3 \mathrm{O}_{2}=23 \mathrm{Cr}+6 \mathrm{CO}$

(2) カーバイドと周相酸化物との反応

(6) $\mathrm{Cr}_{7} \mathrm{C}_{3}+\mathrm{Cr}_{2} \mathrm{O}_{3}=9 \mathrm{Cr}+3 \mathrm{CO}$

(7) $\mathrm{Cr}_{23} \mathrm{C}_{6}+2 \mathrm{Cr}_{2} \mathrm{O}_{3}=27 \mathrm{Cr}+6 \mathrm{CO}$

(8) $3 \mathrm{Cr}_{7} \mathrm{C}_{3}+\mathrm{Cr}_{2} \mathrm{O}_{3}=\mathrm{Cr}_{23} \mathrm{C}_{6}+3 \mathrm{CO}$

これらの反応の一酸化炭素発生分圧を酸素分圧をパラ メーターとして図1に示しだ．まず (1) に属する気一 固相反応を考える，温度が低い場合には酸素分圧の大小

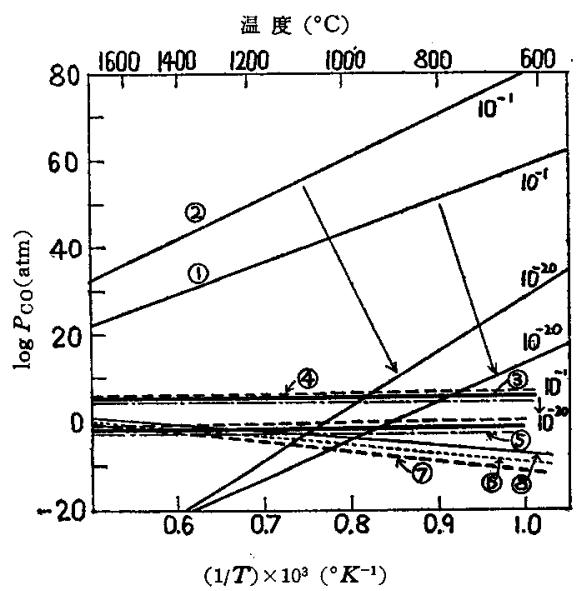

四中の (1)〜(8)の番号は本交中の反店の番号に対応寸る。

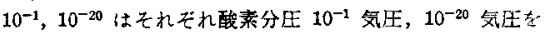
表わ方。

図 1 酸素分圧をパラメーターとした 各反応の $\mathrm{CO}$ 発生圧 